Check for updates

Cite this: RSC Adv., 2019, 9, 3337

Received 29th November 2018 Accepted 11th January 2019

DOI: $10.1039 / c 8 r a 09830 a$

rsc.li/rsc-advances

\section{Acetylacetone functionalized magnetic carbon microspheres for the highly-efficient adsorption of heavy metal ions from aqueous solutions}

\author{
Jie Ma, (D)* Mengya Sun, Yulan Zeng, Zhenhua Liu, Manman Zhang, Yao Xiao \\ and Shuping Zhang
}

\begin{abstract}
Herein, Acac-C $\left(\mathrm{aFe}_{3} \mathrm{O}_{4}\right.$, a magnetic carbon $\left(\mathrm{C}\left(\mathrm{aFe}_{3} \mathrm{O}_{4}\right)\right.$ modified with acetylacetone (Acac), was first prepared and used as a solid-phase adsorbent for adsorbing some heavy metal ions from aqueous solution. The adsorbent was characterized by Fourier transform infrared spectroscopy (FTIR), X-ray diffraction (XRD), scanning electron microscopy (SEM), transmission electron microscopy (TEM), X-ray photoelectron spectroscopy (XPS), vibrating sample magnetometry (VSM) and BET studies. Some parameters affecting the adsorption and desorption processes were studied in $\mathrm{Pb}^{2+}$ solution, including sample $\mathrm{pH}$, contact time, initial concentration, type and connection of the desorption solution. Absorption results showed that removal of $\mathrm{Pb}^{2+}$ was $100 \%$ under optimal conditions at an initial concentration of $10.0 \mathrm{mg} \mathrm{L}^{-1}$. The adsorption mechanism conformed well to a pseudo-second order kinetic model. The adsorption capacity of the sorbent also showed promising results with $\mathrm{Hg}^{2+}, \mathrm{Cr}^{3+}$, $\mathrm{Fe}^{2+}, \mathrm{Cd}^{2+}, \mathrm{Mn}^{2+}, \mathrm{Zn}^{2+}, \mathrm{Cu}^{2+}$ and $\mathrm{Pb}^{2+}$, where maximum adsorption capacities reached 98.0, 151.2, 188.9, 202.2, 286.3, 297.2, 305.1 and $345.3 \mathrm{mg} \mathrm{g}^{-1}$, respectively. The Acac- $\mathrm{CaFe}_{3} \mathrm{O}_{4}$ microsphere material was successfully applied to the adsorption of heavy metal ions in aqueous solution.
\end{abstract}

\section{Introduction}

With the growth of industrial activities, the phenomenon of highly toxic heavy metal ions release to water resources becomes more and more serious. ${ }^{1}$ Heavy metals are difficult to biodegrade and can be enriched hundreds of times during biological amplification of the food chain before entering the human body. Eventually, they will make proteins and enzymes inactive and also cause chronic poisoning. ${ }^{2}$ Thus, it becomes even more necessary to establish a facile and reliable method to deal with environmental pollution of heavy metal ions. Over decades, several technologies have been developed to remove heavy metal ions from wastewaters such as chemical precipitation (including hydroxide precipitation, ${ }^{3}$ sulphide precipitation $^{4}$ and chelating precipitation ${ }^{5}$ ), ion exchange, ${ }^{6}$ membrane filtration (including ultrafiltration, ${ }^{7}$ reverse osmosis and nanofiltration $^{8}$ and electrodialysis ${ }^{9}$ ), coagulation and flocculation, ${ }^{\mathbf{1 0}}$ flotation, ${ }^{11}$ electrochemical treatment $^{\mathbf{1 2}}$ and adsorption. ${ }^{\mathbf{1 3}}$ Adsorption methods draw more attention, because they are simple to pursue without additional consumption, high performing and cost-effective.

With all of the absorbing materials, magnetic nanomaterials are different from others as they can be collected by external

College of Science, University of Shanghai for Science and Technology, Shanghai 200093, P. R. China. E-mail: majie0203ch@hotmail.com; Fax: +86 21 55271663; Tel: $+86-13482433498$ magnetic fields. ${ }^{14}$ This performance provides both adsorption and desorption post-processing for convenience. Meanwhile, low-cost nanosized ferric oxides $\left(\mathrm{Fe}_{3} \mathrm{O}_{4}\right.$ or $\left.\gamma-\mathrm{Fe}_{2} \mathrm{O}_{3}\right)$ possess nontoxicity and superparamagnetism and therefore they have gained even more interest. ${ }^{15}$ Aggregation of these particles can be regulated and controlled by a surface modified process and so far abundant materials have been used as a modified layer including silicon, carbon, synthetic polymers and metals. Among these materials, carbon-based materials are popularly selected because they are easily synthesized and eco-friendly, especially when they have numerous hydrophilic groups and can provide favourable conditions for further modification. ${ }^{\mathbf{1 6}}$ Wang et al. prepared two different structures of carbon-coated $\mathrm{Fe}_{3} \mathrm{O}_{4}$ for lithium storage; both composite materials have good performance and represent a good future for applications. There are also many applications of $\mathrm{Fe}_{3} \mathrm{O}_{4} @ \mathrm{C}$ nanomaterials in the environmental treatment fields. ${ }^{17}$ Liu et al. designed 1D $\mathrm{Fe}_{3} \mathrm{O}_{4} / \mathrm{C} / \mathrm{CdS}$ coaxial nanochains for the degradation of RhB. ${ }^{18}$ Bystrzejewski et al. prepared carbon-encapsulated magnetic nanoparticles to adsorb $\mathrm{Cu}^{2+}, \mathrm{Co}^{2+}$, and $\mathrm{Cd}^{2+}$ and their adsorption capacities were $3.21,1.23$ and $1.77 \mathrm{mg} \mathrm{g}^{-1}$, respectively. ${ }^{19}$ Chen et al. synthesized magnetic core-shell $\mathrm{Fe}_{3} \mathrm{O}_{4} @ \mathrm{C}$ nanoparticles with $-\mathrm{SO}_{3} \mathrm{H} /-\mathrm{COOH}$ groups modified for adsorbing $\mathrm{Pb}^{2+}, \mathrm{Hg}^{2+}$ and $\mathrm{Cd}^{2+}$ ions and their maximum adsorptions were $90.7,83.1$ and $39.7 \mathrm{mg} \mathrm{g}^{-1}$, respectively. ${ }^{20}$ The above-mentioned carbon coated magnetic nanomaterials could be used to adsorb heavy metal ions, but their absorption 
capacities are limited, which may be improved by some new methods.

In order to improve adsorption properties of adsorbents, some chelate molecules, especially multidentate ligands, were selected to modify nanomaterials, such as ethylene diamine tetraacetic acid (EDTA), ethanediamine (EDA) and acetylacetone (Acac), which showed strong coordination with metal ions. Among them, the Acac molecules are superior to other molecules because their active hydrogen and the dicarbonyl structures can be retained during the modification process. ${ }^{21}$ In this work, the magnetic carbon composite $\left(\mathrm{C} @ \mathrm{Fe}_{3} \mathrm{O}_{4}\right)$ was synthesized by a hydrothermal method and functionalized with Acac for adsorbing heavy metal ions in an aqueous solution. Behaviours of the adsorption in different analytical conditions and performance under optimized conditions were investigated by FAAS determination. Meanwhile, the adsorption capacities of the asprepared composites for $\mathrm{Cu}^{2+}, \mathrm{Zn}^{2+}, \mathrm{Mn}^{2+}, \mathrm{Cd}^{2+}, \mathrm{Fe}^{2+}, \mathrm{Hg}^{2+}$ and $\mathrm{Cr}^{3+}$ were measured and had ideal results. Thus the Acac modified $\mathrm{C} @ \mathrm{Fe}_{3} \mathrm{O}_{4}$ microspheres (Acac-C@ $\mathrm{Fe}_{3} \mathrm{O}_{4}$ ) may be used in the metal ion wastewater treatment.

\section{Experimental}

\section{Materials}

All reagents were of analytical grade including $\mathrm{FeCl}_{3} \cdot 6 \mathrm{H}_{2} \mathrm{O}$, $\mathrm{Pb}\left(\mathrm{NO}_{3}\right)_{2} \cdot 6 \mathrm{H}_{2} \mathrm{O}, \quad \mathrm{FeSO}_{4} \cdot 7 \mathrm{H}_{2} \mathrm{O}, \mathrm{CuSO}_{4} \cdot 5 \mathrm{H}_{2} \mathrm{O}, \mathrm{ZnCl}_{2}, \mathrm{HgCl}_{2}$, $\mathrm{CrCl}_{3} \cdot 6 \mathrm{H}_{2} \mathrm{O}, \quad \mathrm{MnSO}_{4}, \mathrm{CdCl}_{2} \cdot 2.5 \mathrm{H}_{2} \mathrm{O}, \mathrm{NaOH}, \mathrm{CH}_{3} \mathrm{COONa}$, ethylene glycol $\left(\mathrm{C}_{2} \mathrm{H}_{6} \mathrm{O}_{2}\right), \quad \mathrm{D}(+)$-glucose monohydrate $\left(\mathrm{C}_{6} \mathrm{H}_{12} \mathrm{O}_{6} \cdot \mathrm{H}_{2} \mathrm{O}\right)$, ethanediamine $\left(\mathrm{C}_{5} \mathrm{H}_{8} \mathrm{O}_{2}\right)$, (3-chloropropyl)triethoxysilane $\left(\mathrm{C}_{9} \mathrm{H}_{21} \mathrm{ClO}_{3} \mathrm{Si}, \mathrm{KH} 230\right)$, acetylacetone (Acac), and $\mathrm{HCl}$ solution and all were purchased from Sinopharm Chemical Reagent Corporation (Shanghai, China). A target stock solution of $\mathrm{Pb}^{2+}$ with $1000.0 \mathrm{mg} \mathrm{L}{ }^{-1}$ was prepared by dissolving proper amounts of $\mathrm{Pb}\left(\mathrm{NO}_{3}\right)_{2} \cdot 6 \mathrm{H}_{2} \mathrm{O}$ and nitric acid in distilled water. Then the solution was further diluted to the given concentrations for testing adsorption capacity and analysing the preconcentration process.

\section{Instrumentation}

The morphology of a sorbent was detected by a field emission scanning electron microscope (SEM, VEGA3 TESCAN, CZ) and a transmission electron microscope (TEM, H800EM Hitachi, JP). Surface area was measured by a BET instrument (TriStar 3020 Micromeritics, CN). XPS spectra were measured by an Xray photoelectron spectroscope (XPS, Thermo ESCALAB 250XI, $\mathrm{CN})$. A Fourier transform infrared spectrophotometry analysis was performed using a FTIR spectrophotometer (FTIR, Nicolet, USA) equipped with a $\mathrm{KBr}$ beam splitter. X-ray diffraction patterns of the samples were recorded by an X-ray powder diffractometer (XRD, D8 advance, DE). Magnetic properties of the sorbent were tested using a vibrating sample magnetometer (VSM, EZ-VSM, MicroSense, USA) at room temperature. Concentrations of metal ions were measured using a flame atomic absorption spectrophotometer with air-acetylene (FAAS, TAS990, China). A digital $\mathrm{pH}$ meter was used for $\mathrm{pH}$ adjustment of the solutions.

\section{Preparation of Acac-C@Fe $\mathrm{Fe}_{3}$}

The synthetic process is shown in Scheme 1. First, a solvothermal method was adopted for synthesizing $\mathrm{Fe}_{3} \mathrm{O}_{4}$ magnetic composites according to a previously reported procedure..$^{22}$ In a typical procedure, $36 \mathrm{mmol}$ of $\mathrm{FeCl}_{3} \cdot 6 \mathrm{H}_{2} \mathrm{O}$ and $200 \mathrm{mmol}$ of $\mathrm{CH}_{3} \mathrm{COONa}$ were dissolved in $350.0 \mathrm{~mL}$ ethylene glycol. The mixture was sonicated for $30 \mathrm{~min}$ and then stirred at room temperature for $2 \mathrm{~h}$. Afterword, the homogeneous solution was transferred into a $500 \mathrm{~mL}$ Teflon-lined stainless-steel autoclave and reacted at $200{ }^{\circ} \mathrm{C}$ for $10 \mathrm{~h}$ followed by cooling down to room temperature naturally. The product was washed with ethanol and distilled water for several times, and then dried in a vacuum freeze-drying apparatus for $5 \mathrm{~h}$.

Secondly, $\mathrm{C} @ \mathrm{Fe}_{3} \mathrm{O}_{4}$ was prepared by a facile hydrothermal method. ${ }^{23,24}$ Concretely, $0.5 \mathrm{~g} \mathrm{Fe}_{3} \mathrm{O}_{4}$ nanoparticles were dispersed in $0.1 \mathrm{~mol} \mathrm{~L}^{-1} \mathrm{HNO}_{3}$ solution and sonicated for $10 \mathrm{~min}$, then were rinsed with distilled water several times until neutral. Subsequently, $8.2 \mathrm{~g}$ glucose was dissolved in $80.0 \mathrm{~mL}$ distilled water, followed by the addition of $0.5 \mathrm{~g} \mathrm{Fe}_{3} \mathrm{O}_{4}$ under sonication. The $\mathrm{pH}$ value of the mixture was adjusted to 8.0 by a $0.1 \mathrm{~mol} \mathrm{~L}^{-1}$ $\mathrm{NaOH}$ solution. Afterwards, the mixture solution was transferred into a Teflon-lined stainless-steel autoclave $(100 \mathrm{~mL}$ capacity) and heated at $170{ }^{\circ} \mathrm{C}$ for $4 \mathrm{~h}$. The precipitate was washed with distilled water for several times and dried in a vacuum freeze-drying apparatus for $5 \mathrm{~h}$, and then the carbon coated $\mathrm{Fe}_{3} \mathrm{O}_{4}$ nanomaterials were obtained.

Thirdly, $1.0 \mathrm{~g} \mathrm{C} \mathrm{Fe}_{3} \mathrm{O}_{4}$ was dissolved in $100.0 \mathrm{~mL}$ waterethanol under mechanical stirring. Then, $1.0 \mathrm{~mL}$ ammonia (25\%) and $3.0 \mathrm{~mL} \mathrm{KH230}$ were added dropwise to the reaction mixture under constant stirring at $45^{\circ} \mathrm{C}$. After $1 \mathrm{~h}$, the reaction mixture was heated to $60{ }^{\circ} \mathrm{C}$ and stirred constantly for $1 \mathrm{~h}$, and then cooled to room temperature. Finally, the magnetic samples $\left(\mathrm{KH} 230-\mathrm{C} @ \mathrm{Fe}_{3} \mathrm{O}_{4}\right)$ were isolated by using an external magnet, washed thoroughly with distilled water and ethanol several times, and then dried in a vacuum freeze-drying apparatus.

Finally, $1.0 \mathrm{~g} \mathrm{NaOH}$ was dissolved in $10.0 \mathrm{~mL}$ distilled water and then was added to $40.0 \mathrm{~mL}$ ethanol in an ice-water bath, $10.0 \mathrm{~mL}$ Acac was added into the mixture, followed by $1.0 \mathrm{~g}$ $\mathrm{KH} 230-\mathrm{C} @ \mathrm{Fe}_{3} \mathrm{O}_{4}$ which was dispersed into the suspension under constant stirring for $0.5 \mathrm{~h}$. Then the mixture was heated to $33{ }^{\circ} \mathrm{C}$ for $7 \mathrm{~h}$. The sample was separated using an external magnetic field and washed several times with distilled water and ethanol and dried in a vacuum freeze-drying apparatus. Finally, Acac$\mathrm{C} @ \mathrm{Fe}_{3} \mathrm{O}_{4}$ composites were prepared successfully.

\section{Adsorption procedure}

Aqueous solutions with different $\mathrm{Pb}^{2+}$ concentrations were prepared and adjusted to a given $\mathrm{pH}$ value by $\mathrm{HCl}$ and $\mathrm{NaOH}$, and then $5.0 \mathrm{mg}$ sorbent was dispersed into the above solution (25.0 $\mathrm{mL}$ ). The time dependence of the adsorption capacity was also examined as a function of contact time from 1 to $8 \mathrm{~min}$ at room temperature using $25.0 \mathrm{~mL}$ of $\mathrm{Pb}^{2+}$ solution $\left(20.0 \mathrm{mg} \mathrm{g}^{-1}\right)$ mixed with $5.0 \mathrm{mg}$ of sorbent. The $\mathrm{Pb}^{2+}$ concentration of a sample was measured by FAAS. The adsorption capacity of the material for $\mathrm{Cu}^{2+}, \mathrm{Zn}^{2+}, \mathrm{Mn}^{2+}, \mathrm{Cd}^{2+}, \mathrm{Fe}^{2+}, \mathrm{Hg}^{2+}$ and $\mathrm{Cr}^{3+}$ were researched under the same conditions. The adsorption process is shown in Fig. 1. 


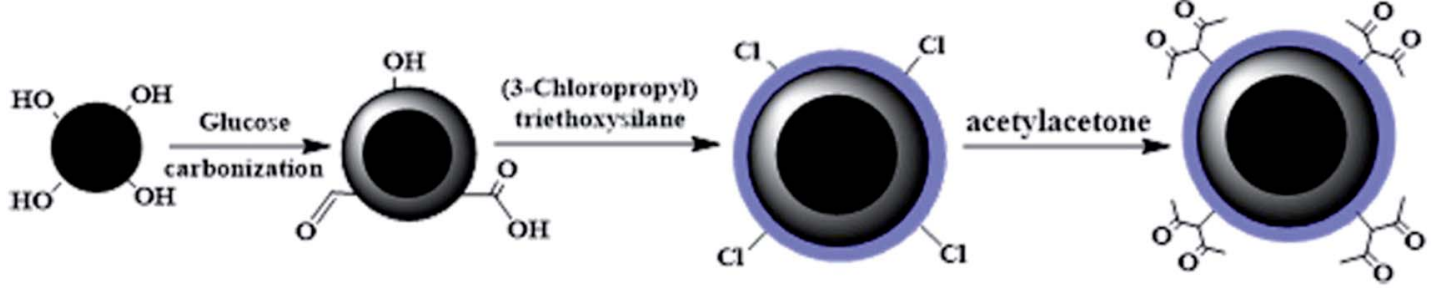

Scheme 1 Diagram of the Acac- $\mathrm{C}\left(\mathrm{aFe}_{3} \mathrm{O}_{4}\right.$ magnetic material synthesis process.

\section{Result and discussion}

\section{Characterization of the magnetic microspheres}

VSM analysis. Fig. 2a depicts the magnetization hysteresis loops of typical samples including $\mathrm{Fe}_{3} \mathrm{O}_{4}, \mathrm{C} @ \mathrm{Fe}_{3} \mathrm{O}_{4}$ and Acac$\mathrm{C} @ \mathrm{Fe}_{3} \mathrm{O}_{4}$ microspheres at room temperature. The curves indicated that all prepared samples had superparamagnetic properties with negligible magnetic remanence and coercivity. Saturation magnetization of samples decreased from 30 to 14 emu $\mathrm{g}^{-1}$ with an increase of coating layer which showed that the obtained samples had enough magnetic response characteristics to meet magnetic separation process.

Meanwhile, the coercivities of samples were almost stable below 20 Oe. The above suggested the modified layer did not affect the superparamagnetic feature of the composites, but just reduced the saturation magnetization of a sample due to the decreased content of $\mathrm{Fe}_{3} \mathrm{O}_{4}$ component in the microspheres.

X-ray diffraction analysis. The XRD patterns of $\mathrm{Fe}_{3} \mathrm{O}_{4}$, $\mathrm{C} @ \mathrm{Fe}_{3} \mathrm{O}_{4}$ and Acac-C@ $\mathrm{Fe}_{3} \mathrm{O}_{4}$ magnetic particles are presented in Fig. 2b. The similar diffraction peaks of all patterns, including $30.1^{\circ}, 35.5^{\circ}, 43.0^{\circ}, 53.6^{\circ}, 57.0^{\circ}$ and $62.6^{\circ}$, indicated the crystal structures of all composites were coincided with a $\mathrm{Fe}_{3} \mathrm{O}_{4}$ standard specimen as a cubic spinel structure (JCPDS, no. 19-0629). ${ }^{25}$ The X-ray diffraction patterns of $\mathrm{C} @ \mathrm{Fe}_{3} \mathrm{O}_{4}$ and Acac-C@ $\mathrm{Fe}_{3} \mathrm{O}_{4}$ were similar with the pattern of $\mathrm{Fe}_{3} \mathrm{O}_{4}$ magnetic particles, which illuminated that they had the same crystal structure and it was not changed during the modification procedures.

FTIR analysis. Composition of the Acac-C@Fe $\mathrm{O}_{4}$ composite was further characterized by FT-IR spectrophotoscopy, and the relevant results are shown in Fig. 2c. The specific stretching vibration absorption peak of $\mathrm{Fe}-\mathrm{O}$ in $\mathrm{Fe}_{3} \mathrm{O}_{4}$ was obviously visible in four spectra at $586 \mathrm{~cm}^{-1}$, which indicated all samples
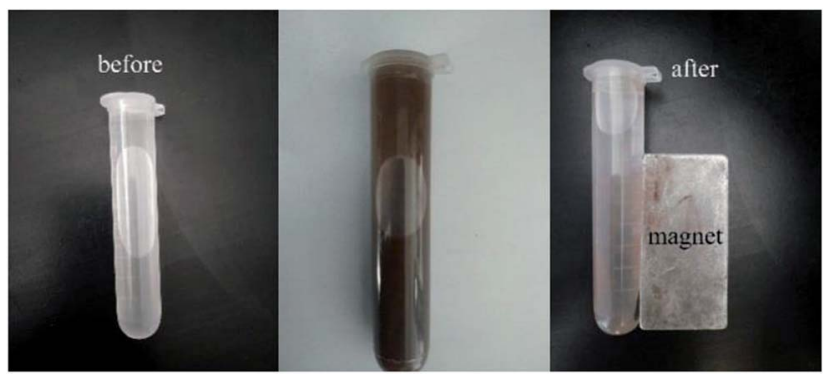

Fig. 1 Schematic diagram of the adsorption process. contained $\mathrm{Fe}_{3} \mathrm{O}_{4}$. The peaks at $1623 \mathrm{~cm}^{-1}$ and $1689 \mathrm{~cm}^{-1}$ were attributed to $\mathrm{C}=\mathrm{C}$ and $\mathrm{C}=\mathrm{O}$ vibrations and illustrated that carbon was successfully coated on the magnetic core. Meanwhile the absorption peak at $3434 \mathrm{~cm}^{-1}$ implied the existence of residual hydroxyl groups, which confirmed that some hydrophilic groups $(-\mathrm{OH})$ and carbonyl group $(-\mathrm{C}=\mathrm{O})$ remained after the process of hydrothermal carbonization treatment. ${ }^{26-28}$ The peak at $802 \mathrm{~cm}^{-1}$ shown in Fig. 2c indicated the existence of C$\mathrm{Cl}$ groups and suggested that $\mathrm{KH} 230$ were grafted on the surface of $\mathrm{C} @ \mathrm{Fe}_{3} \mathrm{O}_{4}$ composites. Curves of Acac-C@Fe $\mathrm{O}_{4}, \mathrm{KH} 230$ $\mathrm{C} @ \mathrm{Fe}_{3} \mathrm{O}_{4}$ and $\mathrm{Fe}_{3} \mathrm{O}_{4}$ are compared and shown in Fig. $2 \mathrm{c}$ and the enhancement of a peak at $1623 \mathrm{~cm}^{-1}$ is attributed to the carbonyl stretching vibration ${ }^{29}$ while the peak at $2915 \mathrm{~cm}^{-1}$ indicated the existence of $-\mathrm{CH}_{3}$ of Acac. These FTIR data indicated that Acac successfully functionalized the $\mathrm{C} @ \mathrm{Fe}_{3} \mathrm{O}_{4}$ magnetic microspheres.

BET analysis. The ratio surface areas of $\mathrm{Fe}_{3} \mathrm{O}_{4}$ and Acac$\mathrm{C} @ \mathrm{Fe}_{3} \mathrm{O}_{4}$ were analysed by nitrogen adsorption-desorption techniques. As Fig. 2d shows, the nitrogen adsorption-desorption isotherms of $\mathrm{Fe}_{3} \mathrm{O}_{4}$ and Acac-C@ $\mathrm{Fe}_{3} \mathrm{O}_{4}$ have representative type-IV curves. The hysteretic loop in the range of $0.6-0.9 P / P_{0}$ is a type of $\mathrm{H} 1$ hysteresis. The BET specific surface area of Acac$\mathrm{C} @ \mathrm{Fe}_{3} \mathrm{O}_{4}$ was measured to be $68.41 \mathrm{~m}^{2} \mathrm{~g}^{-1}$, which is higher than that of $\mathrm{Fe}_{3} \mathrm{O}_{4}\left(37.41 \mathrm{~m}^{2} \mathrm{~g}^{-1}\right)$. This change might be
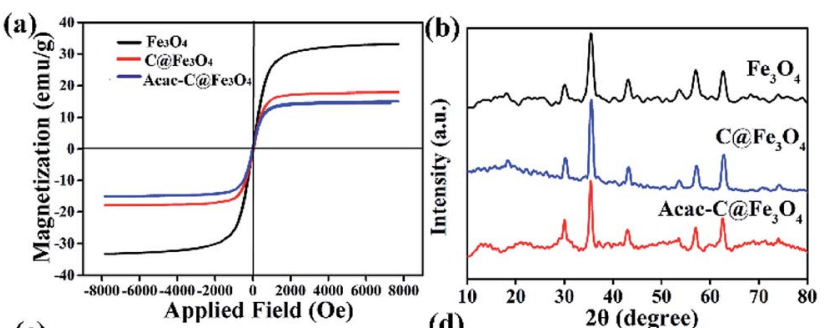

(c)
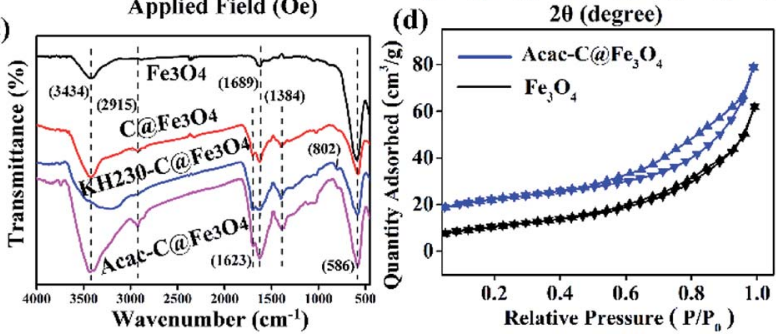

Fig. 2 (a) Magnetization curves of typical prepared samples: $\mathrm{Fe}_{3} \mathrm{O}_{4}$, $\mathrm{C}\left(\mathrm{Fe}_{3} \mathrm{O}_{4}\right.$ and Acac-CaFe $\mathrm{O}_{4}$. (b) XRD patterns of $\mathrm{Fe}_{3} \mathrm{O}_{4}, \mathrm{CaFe}_{3} \mathrm{O}_{4}$ and Acac-CaFe $\mathrm{O}_{4}$. (c) FT-IR spectra of $\mathrm{Fe}_{3} \mathrm{O}_{4}, \mathrm{CaFe}_{3} \mathrm{O}_{4}, \mathrm{KH}_{2} 30$ $\mathrm{CaFe}_{3} \mathrm{O}_{4}$ and $\mathrm{Acac}-\mathrm{C}\left(\mathrm{FFe}_{3} \mathrm{O}_{4}\right.$. (d) Nitrogen adsorption-desorption isotherm of $\mathrm{Fe}_{3} \mathrm{O}_{4}$ and $\mathrm{Acac}-\mathrm{C}\left(\mathrm{aFe}_{3} \mathrm{O}_{4}\right.$. 
attributed to the porous structure of Acac-C@Fe $\mathrm{O}_{4}$ coming from carbon coating.

XPS analysis. The surface element composition of Acac$\mathrm{C} @ \mathrm{Fe}_{3} \mathrm{O}_{4}$ was determined by XPS spectra. As shown in Fig. 3a, the elements of $\mathrm{Fe}, \mathrm{C}, \mathrm{O}$, and $\mathrm{Si}$ were detected on the surfaces of the nanocomposites. The signals of $\mathrm{Fe}$ and $\mathrm{Si}$ were weaker than that of $\mathrm{C}$, indicating that the $\mathrm{Fe}_{3} \mathrm{O}_{4}$ core is coated completely by the carbon shell and a small amount of KH230 was modified. The high-resolution XPS spectrum of Fe 2p can be fitted into two main doublet peaks, as shown in Fig. $3 \mathrm{~b}$. In the high-resolution spectrum, it can be seen that the doublet peak at $710.8 \mathrm{eV}$ and $724.2 \mathrm{eV}$ are assigned to $\mathrm{Fe} 2 \mathrm{p}_{3 / 2}$ and $\mathrm{Fe} 2 \mathrm{p}_{1 / 2}$, which can be attributed to $\mathrm{Fe}(\mathrm{II})$ and $\mathrm{Fe}(\mathrm{III})$ of the $\mathrm{Fe}_{3} \mathrm{O}_{4}$ core. These results were consistent with the XRD analysis. In Fig. 3c, there are more than one chemical state of $\mathrm{C}$ in the $\mathrm{C} 1 \mathrm{~s}$ region; there peaks were identified and assigned to C-C and C-H (284.8 eV), C-O (286.5 $\mathrm{eV}$ ), and $\mathrm{C}=\mathrm{O}$ species (288.4 eV), respectively. These may be ascribed to a carbon shell and acetylacetone. ${ }^{30}$ The XRD results and previous conclusions were combined and provide supportive evidence for the successful modification of carbon and Acac.

SEM and TEM analysis. Morphology and structures of the $\mathrm{Fe}_{3} \mathrm{O}_{4}, \mathrm{C} @ \mathrm{Fe}_{3} \mathrm{O}_{4}$ and Acac- $\mathrm{C} @ \mathrm{Fe}_{3} \mathrm{O}_{4}$ microspheres were characterized by scanning electron microscopy and transmission electron microscopy. Fig. 4 indicated the as-prepared $\mathrm{Fe}_{3} \mathrm{O}_{4}$ materials were monodispersed microspheres, which were further proved by the relative TEM image of $\mathrm{Fe}_{3} \mathrm{O}_{4}$ shown in Fig. 5. The average size of a microsphere is about $260 \mathrm{~nm}$. Fig. 4 also confirmed that the Acac-C@ $\mathrm{Fe}_{3} \mathrm{O}_{4}$ sample still kept spherical morphology with a broader size distribution. The particle distribution range increased slightly, and the average of size of a microsphere increased to $400 \mathrm{~nm}$. The increase of particle sizes and edges of $\mathrm{C} @ \mathrm{Fe}_{3} \mathrm{O}_{4}$ and Acac-C@ $\mathrm{Fe}_{3} \mathrm{O}_{4}$ looked like a light shadow layer should be attributed to the carbon coating on the surface of the magnetic core, which was confirmed directly by the TEM image in Fig. 5. This further indicated that the Acac-C@ $\mathrm{Fe}_{3} \mathrm{O}_{4}$ composite was prepared successfully.

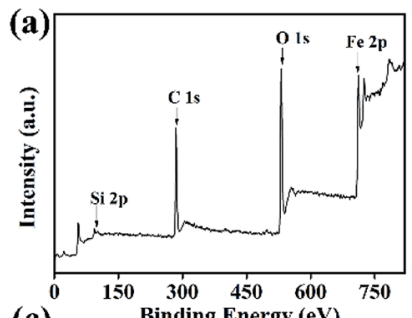

(c)
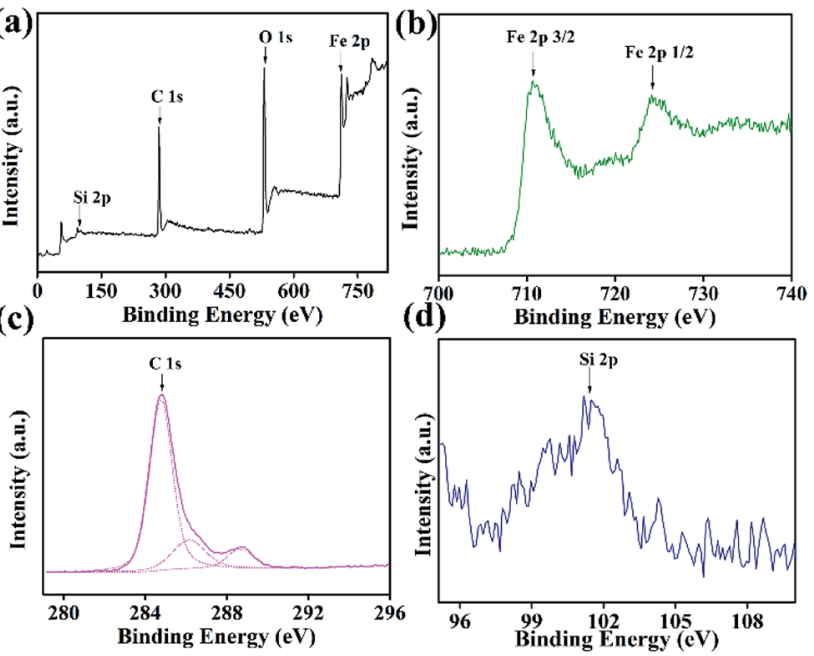

Fig. 3 XPS spectra of Acac- $\mathrm{C}\left(\mathrm{aFe}_{3} \mathrm{O}_{4}\right.$.

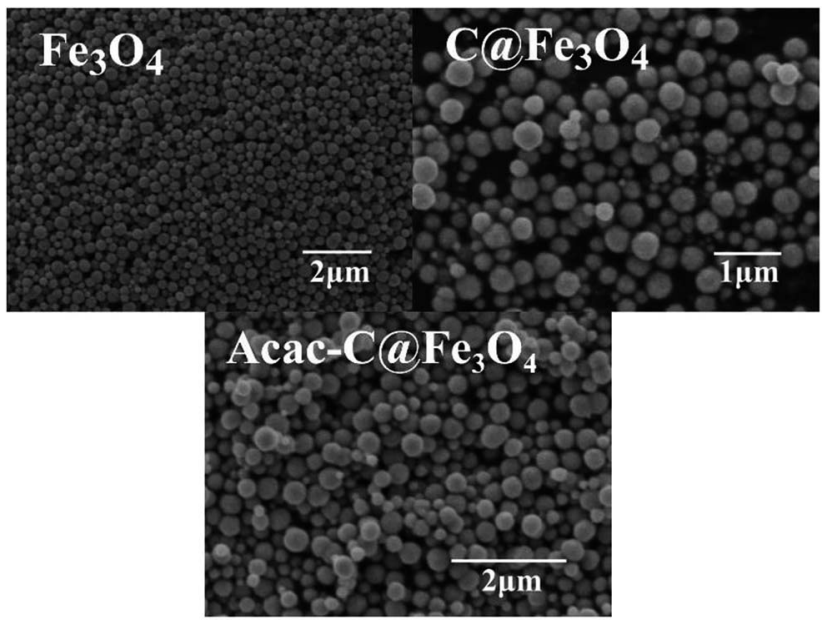

Fig. $4 \mathrm{SEM}$ images of $\mathrm{Fe}_{3} \mathrm{O}_{4}, \mathrm{CaFe}_{3} \mathrm{O}_{4}$ and $\mathrm{Acac}-\mathrm{C}\left(\mathrm{aFe}_{3} \mathrm{O}_{4}\right.$.

\section{Optimization of pre-concentration conditions}

Effect of pH. Acidity of a solution shows strong influence on the adsorption capacity of the adsorbent. To detect influence of the acidity of a solution, $\mathrm{Pb}^{2+}$ was used as the target ion, and the absorbing process was performed at $25{ }^{\circ} \mathrm{C}$ for about 20 minutes. The $\mathrm{pH}$ of the solution was set in a range from 2.0 and 10.0, and concentrations and amounts of solutions were given at $20 \mathrm{mg} \mathrm{L}^{-1}$ and $25.0 \mathrm{~mL}$ in turn with the same amounts of sorbent. The relevant results are shown in Fig. 6a. The curves obviously indicated the absorptivity of $\mathrm{C} @ \mathrm{Fe}_{3} \mathrm{O}_{4}$ was more than $\mathrm{Fe}_{3} \mathrm{O}_{4}$ microsphere in a set range and this may be due to the porous structure of the carbon layer where there are rich oxygenic groups on the surface. The absorptivity of Acac$\mathrm{C} @ \mathrm{Fe}_{3} \mathrm{O}_{4}$ was higher than $\mathrm{C} @ \mathrm{Fe}_{3} \mathrm{O}_{4}$. The absorptivity of Acac$\mathrm{C} @ \mathrm{Fe}_{3} \mathrm{O}_{4}$ was raised from $25 \%$ to $90 \%$ with $\mathrm{pH}$ values from 2.0 to 6.0 and it slightly declined when the $\mathrm{pH}$ changed from 6.0 to 9.0 so the absorptivity was obviously decreased with a $\mathrm{pH}$ beyond 9.0. The above indicated that the proper $\mathrm{pH}$ range should be controlled between 6.0 and 9.0 for better performance of the adsorbent. Compared with the three curves, the result should be attributed to Acac modified on the surface of $\mathrm{C} @ \mathrm{Fe}_{3} \mathrm{O}_{4}$ composites. Acac has convertible enolyl and dicarbonyl structures with the change in acidity. It is beneficial to resist acidity, which helps to form coordination with lead ions. ${ }^{21}$ However, the maximum absorptivity of $\mathrm{Fe}_{3} \mathrm{O}_{4}$ and $\mathrm{C} @ \mathrm{Fe}_{3} \mathrm{O}_{4}$

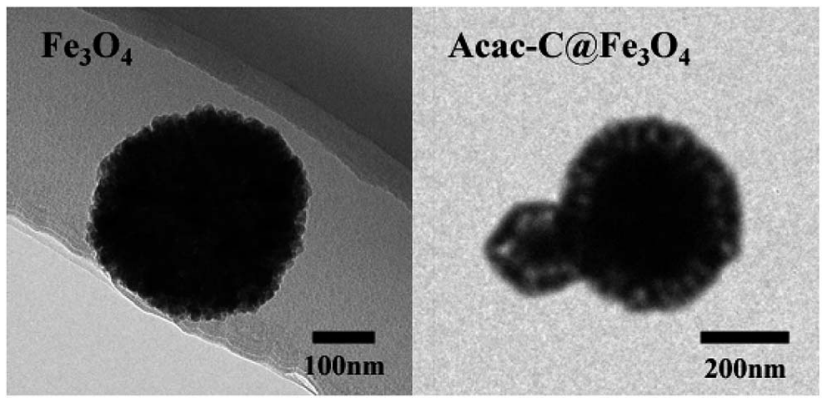

Fig. $5 \mathrm{SEM}$ images of $\mathrm{Fe}_{3} \mathrm{O}_{4}$ and $\mathrm{Acac}-\mathrm{C}\left(\mathrm{Fe}_{3} \mathrm{O}_{4}\right.$. 
(a)
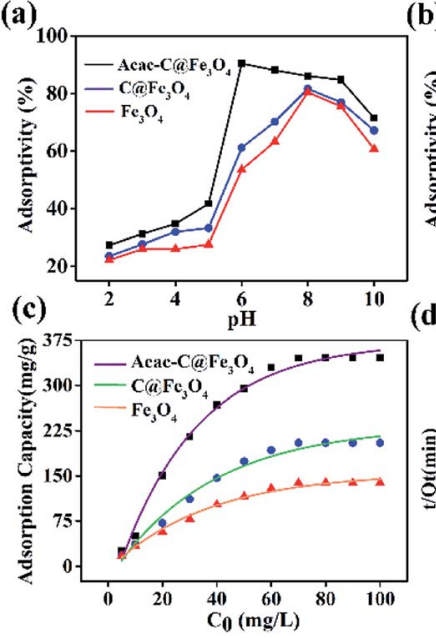

(b)
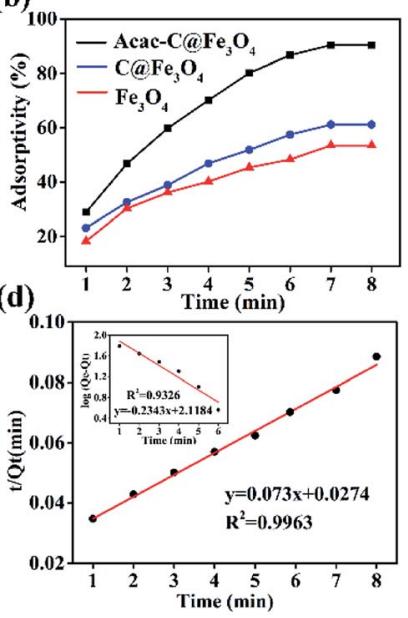

Fig. 6 Effect of $\mathrm{pH}(\mathrm{a})$, adsorption time (b), and initial concentration of $\mathrm{Pb}^{2+}$ (c) on the adsorption of $\mathrm{Pb}^{2+}$ onto Acac-C $a \mathrm{Fe}_{3} \mathrm{O}_{4}, \mathrm{C}^{2} \mathrm{Fe}_{3} \mathrm{O}_{4}$ and $\mathrm{Fe}_{3} \mathrm{O}_{4}$; (d) pseudo-second-order kinetic model for $\mathrm{Pb}^{2+}$ adsorption on Acac-C $\mathrm{aFe}_{3} \mathrm{O}_{4}$ sorbent (inset: pseudo-first-order kinetic model curve)

microspheres $c a$. $80 \%$ appeared at an acidity around 8.0. Since $\mathrm{Pb}^{2+}$ ions can precipitate under basic conditions, this cannot indicate the as-prepared $\mathrm{Fe}_{3} \mathrm{O}_{4}$ microsphere are a suitable lead ion adsorbent although the adsorption capacity is higher in an alkaline setting.

Effect of adsorption time. Adsorption time is an important factor in the application of the as-prepared sorbent. Fig. $6 \mathrm{~b}$ demonstrates the results about absorptivity versus absorbing time at given conditions including the $\mathrm{pH}$ at 6.0, temperature at $25{ }^{\circ} \mathrm{C}$ and concentration of $\mathrm{Pb}^{2+}$ at $20 \mathrm{mg} \mathrm{L}^{-1}$. These three curves indicated that the absorptivity increased rapidly within $7 \mathrm{~min}$ but after that it remained almost unchanged. The adsorption equilibrium of the absorbing system was reached after around 7 minutes, which suggests the Acac-C@ $\mathrm{Fe}_{3} \mathrm{O}_{4}$ adsorbent can achieve the maximum adsorption efficiency within 7 minutes in the testing system, and the adsorption rate of lead ions under the conditions investigated was more than $90 \%$. Relatively, the adsorption rate of lead ions was $61 \%$ absorbed by the $\mathrm{C} @ \mathrm{Fe}_{3} \mathrm{O}_{4}$ microsphere and only $54 \%$ by naked $\mathrm{Fe}_{3} \mathrm{O}_{4}$ at same time. The above indicated that the as-prepared Acac-C@Fe $\mathrm{O}_{3}$ adsorbent had excellent capacity for lead ions, so it could reach the absorption equilibrium quickly. It is beneficial to use the sorbent in the field of separation of heavy metal ions. As the initial concentration of lead ions was raised, the adsorption amount of Acac-C@ $\mathrm{Fe}_{3} \mathrm{O}_{4}$ sorbent also increased gradually and reached to a maximum value greater than $345.3 \mathrm{mg} \mathrm{g}^{-1}$ with a lead ion concentration at $70 \mathrm{mg} \mathrm{L}^{-1}$, thus basically remaining unchanged. Meanwhile, the adsorption capacity of $\mathrm{C} @ \mathrm{Fe}_{3} \mathrm{O}_{4}$ and $\mathrm{Fe}_{3} \mathrm{O}_{4}$ microspheres only reached $205.0 \mathrm{mg} \mathrm{g}^{-1}$ and $138.4 \mathrm{mg} \mathrm{g}^{-1}$, respectively. The maximum adsorption amount of Acac-C@ $\mathrm{Fe}_{3} \mathrm{O}_{4}$ was obviously higher than $\mathrm{C} @ \mathrm{Fe}_{3} \mathrm{O}_{4}$ and the naked $\mathrm{Fe}_{3} \mathrm{O}_{4}$ compared to the three curves. This indicated the saturated adsorption capacity of Acac$\mathrm{C} @ \mathrm{Fe}_{3} \mathrm{O}_{4}$ can be acquired with a lead ion concentration beyond

$70.0 \mathrm{mg} \mathrm{L^{-1 }}$. Because all available adsorption sites of asprepared adsorbent were occupied by ions in a high concentration ion solution, it cannot achieve more amounts of ionic adsorption..$^{31}$ This suggested the absorption process should belong to chemical absorption.

Adsorption kinetics study. An adsorption isotherm expresses the relationship between adsorption capacity and time equilibrium. The experimental data were obtained by detecting the absorbing amount with a series of given absorbing times with the concentration of $\mathrm{Pb}^{2+}$ ions at $70 \mathrm{mg} \mathrm{L}^{-1}$. The corresponding data were calculated according to two Langmuir isotherm model formula including pseudo-first-order (1) and pseudosecond-order eqn (2): ${ }^{32}$

$$
\begin{aligned}
\log \left(Q_{\mathrm{e}}-Q_{t}\right) & =\log Q_{\mathrm{e}}-k_{1}{ }^{t} / 2.303 \\
\frac{t}{Q_{t}} & =\frac{1}{k_{2} Q_{\mathrm{e}}{ }^{2}}+\frac{t}{Q_{\mathrm{e}}}
\end{aligned}
$$

where $Q_{\mathrm{e}}$ and $Q_{t}$ refer to the adsorption amount of $\mathrm{Pb}^{2+}$ at equilibrium and time $t$, respectively, and $k_{1}, k_{2}$ are the rate constants of pseudo-first-order and pseudo-second-order.

According to the model formula, two linear fitting curves and equations are separately shown in Fig. 6d. The analysis results suggested that the pseudo-second-order model $\left(R^{2}=0.9915\right)$ provided a better description of the $\mathrm{Pb}^{2+}$ adsorption isotherm process than the pseudo-first-order model based on the fitted correlation coefficients $\left(R^{2}\right) 0.996$ for the second order and 0.933 for the first order model. These results further suggested the absorbing process belongs to a chemical process.

Adsorption of other heavy metal ions. Due to Acac having a strong coordination capacity with many metal ions, the sorption capacity of the as-prepared absorbent for various common metal ions $\mathrm{Hg}^{2+}, \mathrm{Cr}^{3+}, \mathrm{Fe}^{2+}, \mathrm{Cd}^{2+}, \mathrm{Mn}^{2+}, \mathrm{Zn}^{2+}$ and $\mathrm{Cu}^{2+}$ ) were investigated in parallel under the same conditions. The concentration of all them was given at $70 \mathrm{mg} \mathrm{L}^{-1}$ with the same optimal conditions as the $\mathrm{Pb}^{2+}$ adsorbing procedures. All data are shown in Fig. 7. This showed that the absorbing capacities of the Acac-C@ $\left(\mathrm{Fe}_{3} \mathrm{O}_{4}\right.$ sorbent on $\mathrm{Hg}^{2+}, \mathrm{Cr}^{3+}, \mathrm{Fe}^{2+}$, $\mathrm{Cd}^{2+}, \mathrm{Mn}^{2}+, \mathrm{Zn}^{2+}$ and $\mathrm{Cu}^{2+}$ were 98.0, 151.2, 189.9, 202.2, 286.3, 297.2 and $305.1 \mathrm{mg} \mathrm{g}^{-1}$, respectively. These results illustrated that the Acac-C@ $\mathrm{Fe}_{3} \mathrm{O}_{4}$ composites can be applied as a highly efficient sorbent for absorbing some common metal ions, which was beneficial for enriching some metal ions in aqueous solution. In order to measure the quality of the prepared adsorbents, saturated adsorbents were compared with some reported metal ion adsorbents and are shown in Table 1. These data indicated that the as-prepared Acac-C@ $@ \mathrm{Fe}_{3} \mathrm{O}_{4}$ adsorbent presented outstanding advantages in adsorption capacity which should be attributed to the functionalization of $\mathrm{Fe}_{3} \mathrm{O}_{4}$ microspheres by Acac and carbon.

\section{Regeneration of the sorbent}

Selection of a desorption solution. Regeneration property and method are important parameters to evaluate an adsorbent. Regeneration of the Acac-C@ $\mathrm{Fe}_{3} \mathrm{O}_{4}$ composite materials was investigated. First, the type of desorption solution was 


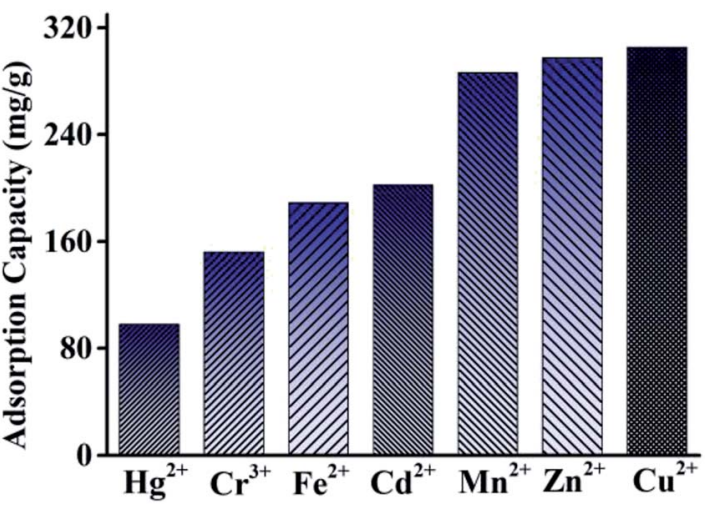

Fig. 7 The adsorption capacity of the as-prepared sorbent for other heavy metal ions.

selected from four kind of common solutions $\left(\mathrm{H}_{2} \mathrm{SO}_{4}, \mathrm{HNO}_{3}\right.$ and $\mathrm{HCl}$ at $1 \mathrm{~mol} \mathrm{~L}^{-1}$ and EDTA at $\left.0.5 \mathrm{~mol} \mathrm{~L}^{-1}\right)$. They were used to desorb $\mathrm{Pb}^{2+}$ from the magnetic sorbent and the desorption efficiencies of them are shown in Fig. 8a. This proved that a $\mathrm{HCl}$ solution was the most suitable for use for desorption because it had the highest effective desorption among those tested. On this basis, the influence of the concentration of a $\mathrm{HCl}$ solution was further explored and the data are shown in Fig. 8a. With an increase of the $\mathrm{HCl}$ concentration desorption efficiency increased as the solution concentration changed from 0.2 to $2.0 \mathrm{~mol} \mathrm{~L}^{-1}$, and then the desorption efficiency decreased slightly. The above results indicated that desorption solution acidity was an important factor for desorbing lead ion from the as-prepared magnetic sorbent. The coordination sites with $\mathrm{Pb}^{2+}$ were more and more occupied by $\mathrm{H}^{+}$with increased concentration of the $\mathrm{HCl}$ solution, so high acidity was an advantage to regenerate the sorbent. However, when concentration of desorption solution was beyond $2.0 \mathrm{~mol} \mathrm{~L}^{-1}$, the desorption performance could keep a high level, but the colour of the desorption solution changed to pale yellow, which might be due to $\mathrm{Fe}^{3+}$ ion being generated and suggesting that Acac-C@ $\mathrm{Fe}_{3} \mathrm{O}_{4}$ materials were damaged in a high acidic setting. So, the concentration of the $\mathrm{HCl}$ solution used as a desorption solution should be controlled between 1.0 and $2.0 \mathrm{~mol} \mathrm{~L}^{-1}$ when desorption efficiency of Acac-C@ $\mathrm{Fe}_{3} \mathrm{O}_{4}$ sorbent is beyond 95\%.

Meanwhile, the effects of $\mathrm{HCl}$ solution volume and desorption time on desorption were also studied. The desorbed efficiency was obviously raised with the increase of $\mathrm{HCl}$ solution volume under $50.0 \mathrm{~mL}$ as shown in Fig. 8b. There was no change
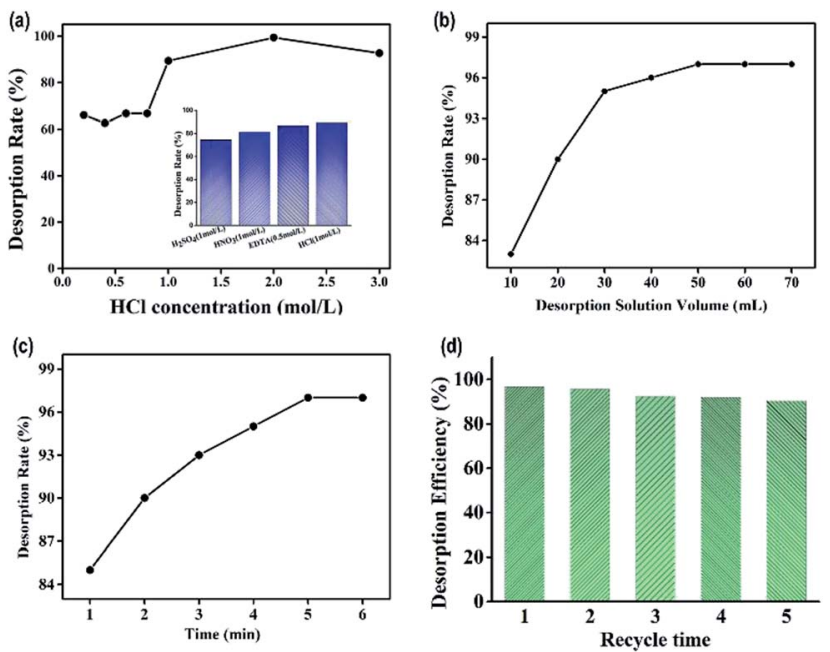

Fig. 8 (a) Influence of the concentration of $\mathrm{HCl}$ solution and the kind of desorption solution (inset) on the desorption efficiency; the influence of desorption solution volume (b) and desorption time (c) on the desorption efficiency; (d) desorption and regeneration of the asprepared sorbent.

when the volume was more than $50.0 \mathrm{~mL}$. Hence, $50.0 \mathrm{~mL}$ desorption solution was used in subsequent research. The desorbed time also affects the desorption process. Fig. 8c showed the recovery of the lead ions was up to $97 \%$ when the desorbed time was $5 \mathrm{~min}$. And then, the desorption efficiency kept stable even if time was increased. So we choose $5 \mathrm{~min}$ as optimum desorption.

Reuse studies. The reusability of a sorbent is crucial in practical applications. Fig. $8 d$ indicated the results from five time's consecutive adsorption-desorption cycles of $\mathrm{Pb}^{2+}$ on the Acac-C@ $\mathrm{Fe}_{3} \mathrm{O}_{4}$ microspheres. The desorption efficiency still maintained beyond $90 \%$ after 5 times which clearly indicated that absorption capacity just decreased slightly and this decrease of sorption efficiency may be ascribed to loss of adsorbents in a recycled application. The above experimental results suggest our as-prepared Acac-C@ $\mathrm{Fe}_{3} \mathrm{O}_{4}$ microspheres sorbent possess fine reusability.

\section{Conclusions}

An Acac-C@ $\mathrm{Fe}_{3} \mathrm{O}_{4}$ magnetic adsorbent was successfully prepared by a simple and sustainable procedure and its structure and properties were detected via numerous instrumental

Table 1 Comparison of the adsorption capacities of different adsorbents for the removal of heavy metal ions

Adsorption capacity of metal ions $\left(\mathrm{mg} \mathrm{g}^{-1}\right)$

\begin{tabular}{|c|c|c|c|c|c|c|c|c|c|}
\hline Adsorbent & $\mathrm{Hg}^{2+}$ & $\mathrm{Cr}^{3+}$ & $\mathrm{Fe}^{2+}$ & $\mathrm{Cd}^{2+}$ & $\mathrm{Mn}^{2+}$ & $\mathrm{Zn}^{2+}$ & $\mathrm{Cu}^{2+}$ & $\mathrm{Pb}^{2+}$ & Ref. \\
\hline Acac-C@ $\mathrm{Fe}_{3} \mathrm{O}_{4}$ & 98.0 & 151.2 & 188.9 & 202.2 & 286.3 & 297.2 & 305.1 & 345.3 & This work \\
\hline PEI-magnetic porous & - & - & - & 105.2 & - & 138.8 & 157.8 & - & 33 \\
\hline $\mathrm{Fe}_{3} \mathrm{O}_{4} @ \mathrm{C}-\mathrm{SO}_{3} \mathrm{H} /-\mathrm{COOH}$ & 83.1 & - & - & 39.7 & - & - & - & 90.7 & 20 \\
\hline $\mathrm{Fe}_{3} \mathrm{O}_{4} @ \mathrm{APS} @ \mathrm{AA}-\mathrm{co}-\mathrm{CA}$ & - & - & - & 29.6 & - & 43.4 & 126.9 & 166.1 & 34 \\
\hline Magnetic PSSQ hybrid & - & - & - & 5.2 & 13.3 & - & 30.0 & 66.1 & 35 \\
\hline Poly(MMA-co-MA)/Fe ${ }_{3} \mathrm{O}_{4}$ & - & 90.91 & - & - & - & 111.11 & 109.89 & - & 36 \\
\hline Coir fibers & - & - & 11.11 & - & - & - & 9.43 & 24.91 & 37 \\
\hline
\end{tabular}


measurements. The adsorbent demonstrated outstanding adsorption capacity for some metal ions. Under given conditions, the maximum adsorption capacities for $\mathrm{Hg}^{2+}, \mathrm{Cr}^{3+}, \mathrm{Fe}^{2+}$, $\mathrm{Cd}^{2+}, \mathrm{Mn}^{2+}, \mathrm{Zn}^{2+}, \mathrm{Cu}^{2+}$ and $\mathrm{Pb}^{2+}$ were 98.0, 151.2, 188.9, 202.2, $286.3,297.2$, 335.1 and $345.3 \mathrm{mg} \mathrm{g}^{-1}$, respectively. The adsorption process reached adsorption equilibrium within $7 \mathrm{~min}$ and conforms to a pseudo-second-order kinetics model. The adsorbent had excellent stability and reusability. The Acac$\mathrm{C} @ \mathrm{Fe}_{3} \mathrm{O}_{4}$ magnetic adsorbent may provide an alternative for applications in the adsorption and separation of heavy metal ions in aqueous solutions. What's more, the material can be used as a substrate and in the further synthesis of metalorganic frameworks.

\section{Conflicts of interest}

There are no conflicts to declare.

\section{Acknowledgements}

This work was financially supported by the Natural Science Foundation of Shanghai (No. 15ZR1428500) and the National Natural Science Foundation of China (No. 20906061).

\section{Notes and references}

1 Z. S. Kardar, M. H. Beyki and F. Shemirani, Takovitealuminosilicate@ $\mathrm{MnFe}_{2} \mathrm{O}_{4}$ nanocomposite, a novel magnetic sorbent for efficient preconcentration of lead ions in food samples, Food Chem., 2016, 209, 241-247.

2 F. L. Fu and Q. Wang, Removal of heavy metal ions from wastewaters: a review, J. Environ. Manage., 2011, 92(3), 407418.

3 F. R. Peligro, I. Pavlovic, R. Rojas and C. Barriga, Removal of heavy metals from simulated wastewater by in situ formation of layered double hydroxides, Chem. Eng. J., 2016, 336, 10351040.

4 H. Wang, F. Chen, S. Mu, D. Zhang, X. Pan, D. J. Lee and J. S. Chang, Removal of antimony ( $\mathrm{Sb}(\mathrm{V})$ ) from $\mathrm{Sb}$ mine drainage: biological sulfate reduction and sulfide oxidation-precipitation, Bioresour. Technol., 2013, 146, 799802.

5 F. Fu, L. Xie, B. Tang, Q. Wang and S. Jiang, Application of a novel strategy-Advanced Fenton-chemical precipitation to the treatment of strong stability chelated heavy metal containing wastewater, Chem. Eng. J., 2012, 189, 283-287.

6 S. J. Kim, K. H. Lim, K. H. Joo, M. J. Lee, S. G. Kil and S. Y. Cho, Removal of heavy metal-cyanide complexes by ion exchange, Korean J. Chem. Eng., 2002, 19(6), 1078-1084.

7 X. Li, G. M. Zeng, J. H. Huang, C. Zhang, Y. Y. Fang, Y. H. Qu, F. Luo, D. Lin and H. L. Liu, Recovery and reuse of surfactant SDS from a MEUF retentate containing $\mathrm{Cd}^{2+}$ or $\mathrm{Zn}^{2+}$ by ultrafiltration, J. Membr. Sci., 2009, 337(1-2), 92-97.

8 C. M. Zhong, Z. L. Xu, X. H. Fang and L. Cheng, Treatment of acid mine drainage (AMD) by ultra-low-pressure reverse osmosis and nanofiltration, Environ. Eng. Sci., 2007, 24(9), 1297-1336.
9 K. I. Dermentzis, A. E. Davidis, A. S. Dermentzi and C. D. Chatzichristou, An electrostatic shielding-based coupled electrodialysis/electrodeionization process for removal of cobalt ions from aqueous solutions, Water Sci. Technol., 2010, 62(8), 1947-1953.

10 C. Y. Teh, P. M. Budiman, K. P. Y. Shak and T. Y. Wu, Recent advancement of coagulation-flocculation and its application in wastewater treatment, Ind. Eng. Chem. Res., 2016, 55(16), 4363-4389.

$11 \mathrm{H}$. Polat and D. Erdogan, Heavy metal removal from waste waters by ion flotation, J. Hazard. Mater., 2007, 148(1-2), 267-273.

12 T. K. Tran, H. J. Leu, K. F. Chiu and C. Y. Lin, Electrochemical Treatment of Heavy Metal-containing Wastewater with the Removal of COD and Heavy Metal Ions, J. Chin. Chem. Soc., 2017, 64(5), 493-502.

$13 \mathrm{H}$. B. Bradl, Adsorption of heavy metal ions on soils and soils constituents, J. Colloid Interface Sci., 2004, 277(1), 1-18.

14 X. Li, S. F. Wang, Y. G. Liu, L. H. Jiang, B. Song, M. F. Li, G. M. Zeng, X. F. Tan, X. X. Cai and Y. Ding, Adsorption of $\mathrm{Cu}$ (II), $\mathrm{Pb}$ (II), and $\mathrm{Cd}$ (II) ions from acidic aqueous solutions by diethylenetriamine- pentaacetic acid-modified magnetic graphene oxide, J. Chem. Eng. Data, 2016, 62(1), 407-416.

15 M. Hua, S. J. Zhang, B. C. Pan, W. M. Zhang, L. Lv and Q. X. Zhang, Heavy metal removal from water/wastewater by nanosized metal oxides: a review, J. Hazard. Mater., 2012, 211, 317-331.

16 Y. L. Wang, X. Zhang, L. Gao, Y. Mao, X. Hu and W. D. Lou, One-Pot Magnetic Field Induced Formation of $\mathrm{Fe}_{3} \mathrm{O}_{4} / \mathrm{C}$ Composite Microrods with Enhanced Lithium Storage Capability, Small, 2014, 10(14), 2815-2819.

17 Y. L. Wang, Y. Zhang, Y. Wu, Y. Zhong, X. Hu and W. D. Lou, Carbon-coated $\mathrm{Fe}_{3} \mathrm{O}_{4}$ microspheres with a porous multideck-cage structure for highly reversible lithium storage, Chem. Commun., 2015, 51(32), 6921-6924.

18 Y. Liu, L. Zhou, Y. Hu, C. Guo, H. Qian, F. X. Zhang and W. D. Lou, Magnetic-field induced formation of $1 \mathrm{D} \mathrm{Fe}_{3} \mathrm{O}_{4} /$ $\mathrm{C} / \mathrm{CdS}$ coaxial nanochains as highly efficient and reusable photocatalysts for water treatment, J. Mater. Chem., 2011, 21(45), 18359-18364.

19 M. Bystrzejewski, K. Pyrzyńska, A. Huczko and H. Lange, Carbon-encapsulated magnetic nanoparticles as separable and mobile sorbents of heavy metal ions from aqueous solutions, Carbon, 2009, 47(4), 1201-1204.

20 Z. Chen, Z. Geng, Z. Zhang, L. b. Ren, T. T. Tao, R. C. Yang and Z. X. Guo, Synthesis of magnetic $\mathrm{Fe}_{3} \mathrm{O}_{4} @ \mathrm{C}$ nanoparticles modified with $-\mathrm{SO}_{3} \mathrm{H}$ and $-\mathrm{COOH}$ groups for fast removal of $\mathrm{Pb}^{2+}, \mathrm{Hg}^{2+}$, and $\mathrm{Cd}^{2+}$ ions, Eur. J. Inorg. Chem., 2014, (20), 3172-3177.

21 M. H. Xu, J. Chai, N. T. Hu, D. Huang, Y. X. Wang, X. L. Huang, H. Wei, Z. Yang and Y. F. Zhang, Facile synthesis of soluble functional graphene by reduction of graphene oxide via acetylacetone and its adsorption of heavy metal ions, Nanotechnology, 2014, 25(39), 395602.

22 S. H. Liu, R. M Xing, F. Lu, R. K. Rana and J. J. Zhu, One-pot template-free fabrication of hollow magnetite nanospheres 
and their application as potential drug carriers, J. Phys. Chem. C, 2009, 113(50), 21042-21047.

23 X. Y. Zhang, S. C. Zhu, C. H. Deng and X. M. Zhang, Highly sensitive thrombin detection by matrix assisted laser desorption ionization-time of flight mass spectrometry with aptamer functionalized core-shell $\mathrm{Fe}_{3} \mathrm{O}_{4} @ \mathrm{C} @ \mathrm{Au}$ magnetic microspheres, Talanta, 2012, 88, 295-332.

24 Q. H. Li, X. Z. Ren, L. Z. Tong, X. D. Chen, H. Ding and H. Yang, Deposition of luminescence $\mathrm{YBO}_{3}: \mathrm{Eu}^{3+}, \mathrm{Gd}^{3+}$ on ferromagnetic Fe@ C nanoparticles, Dyes Pigm., 2014, 107, 161-165.

25 X. F. Lu, H. Mao, D. M. Chao, W. J. Zhang and Y. Wei, Ultrasonic synthesis of polyaniline nanotubes containing $\mathrm{Fe}_{3} \mathrm{O}_{4}$ nanoparticles, J. Solid State Chem., 2006, 179(8), 2609-2615.

26 Z. Y. Zhang and J. L. Kong, Novel magnetic $\mathrm{Fe}_{3} \mathrm{O}_{4}$ @C nanoparticles as sorbents for removal of organic dyes from aqueous solution, J. Hazard. Mater., 2011, 193, 325-329.

27 J. R. Meng, C. Y. Shi, B. W. Wei, W. J. Yu, C. H. Deng and X. M. Zhang, Preparation of $\mathrm{Fe}_{3} \mathrm{O}_{4} @ \mathrm{C} @ P A N I$ magnetic microspheres for the extraction and analysis of phenolic compounds in water samples by gas chromatographymass spectrometry, J. Chromatogr. A, 2011, 1218(20), 28412847.

28 S. K. Li, F. Z. Huang, Y. Wang, Y. H. Shen, L. G. Qiu, A. J. Xie and S. J. Xu, Magnetic $\mathrm{Fe}_{3} \mathrm{O}_{4} @ \mathrm{C} @ \mathrm{Cu}_{2} \mathrm{O}$ composites with bean-like core/shell nanostructures: synthesis, properties and application in recyclable photocatalytic degradation of dye pollutants, J. Mater. Chem., 2011, 21(20), 7459-7466.

29 D. Saberi, S. Mahdudi, S. Cheraghi and A. Heydari, Cu (II)acetylacetone complex covalently anchored onto magnetic nanoparticles: Synthesis, characterization and catalytic evaluation in amide bond formation via oxidative coupling of carboxylic acids with $\mathrm{N}, \mathrm{N}$-dialkylformamides, $J$. Organomet. Chem., 2014, 772, 222-228.

30 C. Guo, W. Lu, G. Wei, L. Jiang, Y. Yu and Y. Hu, Formation of $1 \mathrm{D}$ chain-like $\mathrm{Fe}_{3} \mathrm{O}_{4} @ \mathrm{C} / \mathrm{Pt}$ sandwich nanocomposites and their magnetically recyclable catalytic property, Appl. Surf. Sci., 2018, 457, 1136-1141.

31 K. Wang, J. W. Gu and N. Yin, Efficient Removal of Pb (II) and Cd (II) Using NH2-Functionalized Zr-MOFs via Rapid Microwave-Promoted Synthesis, Ind. Eng. Chem. Res., 2017, 56(7), 1880-1887.

32 G. X. Chen, C. D. Qiao, Y. Wang and J. S. Yao, Synthesis of magnetic gelatin and its adsorption property for $\mathrm{Cr}$ (VI), Ind. Eng. Chem. Res., 2014, 53(40), 15576-15581.

33 Y. Pang, G. Zeng, L. Tang, Y. Zhang, Y. Y. Liu, X. X. Lei, Z. Li, J. C. Zhang and G. X. Xie, PEI-grafted magnetic porous powder for highly effective adsorption of heavy metal ions, Desalination, 2011, 281, 278-284.

34 F. Ge, M. M. Li, H. Ye and B. X. Zhao, Effective removal of heavy metal ions $\mathrm{Cd}^{2+}, \mathrm{Zn}^{2+}, \mathrm{Pb}^{2+}, \mathrm{Cu}^{2+}$ from aqueous solution by polymer-modified magnetic nanoparticles, $J$. Hazard. Mater., 2012, 211, 366-372.

35 S. Nagappan, H. M. Ha, S. S. Park, N. J. Jo and C. S. Ha, Onepot synthesis of multi-functional magnetitepolysilsesquioxane hybrid nanoparticles for the selective $\mathrm{Fe}^{3+}$ and some heavy metal ions adsorption, RSC Adv., 2017, 7(31), 19106-19116.

36 A. Masoumi, M. Ghaemy and A. N. Bakht, Removal of metal ions from water using poly (MMA-co-MA)/modified- $\mathrm{Fe}_{3} \mathrm{O}_{4}$ magnetic nanocomposite: isotherm and kinetic study, Ind. Eng. Chem. Res., 2014, 53(19), 8188-8197.

37 P. M. Shukla and S. R. Shukla, Biosorption of $\mathrm{Cu}$ (II), Pb (II), Ni (II), and Fe (II) on alkali treated coir fibers, Sep. Sci. Technol., 2013, 48(3), 421-428. 